\title{
Algorithmization of the optimization apparatus in the organization of the current planning at the companies of the building complex
}

\author{
Pavel Oleinik ${ }^{1}$ and Alexey Yurgaytis, ${ }^{1, *}$ \\ ${ }^{1}$ Moscow State University of Civil Engineering, 129337, 26, Yaroslavskoye Shosse, Moscow, Russia
}

\begin{abstract}
The issue of optimizing the decisions of the planning system at various levels and stages of construction production is one of the most important aspects of managerial and engineering activities at the construction enterprise. Such optimization is a complex multifactorial task, the solutions of which are reflected in the established documents based on the results of planning. The main document in this respect is the production and economic program (plan) developed by the planning and economic department of the corresponding construction enterprise, depending on the existing destabilizing factors and constraints established by the results of the integrated planning procedure (annual and strategic). The article discusses the concept of the annual production program of a construction company and a new approach to optimize the algorithm for distributing the resource potential between objects of the annual program.
\end{abstract}

\section{Introduction}

The concept of the annual production and economic plan (program) for the RussianSoviet building complex emerged in the 1920s in the development of future so-called "fiveyear plans" aimed at an effective and dynamic breakthrough in the country's economic development (including the USSR) (see Tables 1,2) through the development and production implementation of target indicators of socio-economic development in the programs of companies. Such planned economy with rigidly fixed performance indicators of programs formed the prerequisites for the development of the annual (or as it is called in the technical literature - current) planning of the construction enterprise activity, which could include in its integrated solution system the most optimal ways to implement the established plan for the facilities in the required time frame and with the lowest possible cost of all types of resources. So, you can refer to developments in the field of methodological support of planning activities of the production system (program) of a construction enterprise, which, for example, in the USSR was carried out by the Research Institute of Construction Economics (RICE). This organization in 1982 published the next edition of the "Methodological recommendations on the preparation of the production and economic plan (production and estimation plan) of construction organizations", which describes in detail the methodology for the preparation of this current planning document.

*Corresponding author: aljurgaitis@gmail.com 
Table 1. The history of the application of the experience of five years of planning in the production and economic models of various countries.

\begin{tabular}{|l|c|c|c|}
\hline No. & $\begin{array}{c}\text { Some countries of the socialist bloc } \\
\text { Union of Soviet Socialist Republics } \\
\text { (USSR) (from 1928 to 1991) }\end{array}$ & $\begin{array}{c}\text { Some countries of the non- } \\
\text { socialist bloc }\end{array}$ & $\begin{array}{c}\text { Apply five year planning } \\
\text { now }\end{array}$ \\
\hline 2. & Albania (since 1951) & Afghanistan (since 1957) & Vietnam (since 1958) \\
\hline 3. & Bulgaria (since 1948) & Egypt (since 1960) & $\begin{array}{c}\text { India (since April 1, } \\
\text { 1951) }\end{array}$ \\
\hline 4. & Hungary (since 1950) & Indonesia (since 1956) & $\begin{array}{c}\text { People's Republic of } \\
\text { China (since 1953) }\end{array}$ \\
\hline 5. & Poland & Iraq (since 1970) & Malaysia (since 1966) \\
\hline 6. & Romania (from 1951 to 1989) & Iran (since 1948) & Bhutan (since 1961) \\
\hline 7. & Czechoslovakia (since 1949) & Morocco (since 1968) & - \\
\hline 8. & Cuba (since 1976) & Japan & - \\
\hline 9. & Mongolia (since 1945) & Turkey & - \\
\hline 10. & - & South Korea & - \\
\hline
\end{tabular}

Table 2. Five-year plans for the development of the national economy of the USSR.

\begin{tabular}{|c|c|c|c|}
\hline No. & Period & Name of the approving document & Note \\
\hline 1 & $1928-1932$ & $\begin{array}{l}\text { Directives on the compilation of a five-year } \\
\text { national economic development plan }\end{array}$ & I five year plan \\
\hline 2 & $1933-1937$ & $\begin{array}{l}\text { Resolution "On the second five-year plan for the } \\
\text { development of the national economy of the } \\
\text { USSR" }\end{array}$ & II five year plan \\
\hline 3 & $1938-1942$ & $\begin{array}{l}\text { Resolution XVIII Congress of the CPSU (b) on the } \\
\text { report of Comrade. Molotov }\end{array}$ & $\begin{array}{l}\text { III five-year plan - thwarted } \\
\text { by the beginning of the Great } \\
\text { Patriotic War }\end{array}$ \\
\hline 4 & $1946-1950$ & $\begin{array}{l}\text { Law on the Five-Year Plan for the Restoration and } \\
\text { Development of the National Economy (for 1946- } \\
\text { 1950) }\end{array}$ & IV five year plan \\
\hline 5 & $1951-1955$ & $\begin{array}{l}\text { Directives on the five-year plan for the } \\
\text { development of the national economy of the USSR }\end{array}$ & V five year plan \\
\hline 6 & $1956-1960$ & $\begin{array}{l}\text { Directives on the five-year plan for the } \\
\text { development of the national economy of the USSR }\end{array}$ & $\begin{array}{l}\text { VI five-year plan - was not } \\
\text { completed, the Seven-Year } \\
\text { Plan was adopted for the } \\
\text { period from } 1959 \text { to } 1965\end{array}$ \\
\hline 7 & $1959-1965$ & $\begin{array}{l}\text { Directives on the seven-year plan for the } \\
\text { development of the national economy of the USSR }\end{array}$ & Seven year plan \\
\hline 8 & $1966-1970$ & $\begin{array}{l}\text { Directives on the five-year plan for the } \\
\text { development of the national economy of the USSR }\end{array}$ & VIII five year plan \\
\hline 9 & $1971-1975$ & $\begin{array}{l}\text { Directives on the five-year plan for the } \\
\text { development of the national economy of the USSR }\end{array}$ & IX five year plan \\
\hline 10 & $1976-1980$ & $\begin{array}{l}\text { The main directions of development of the national } \\
\text { economy of the USSR for 1976-1980. }\end{array}$ & $\mathrm{X}$ five year plan \\
\hline 11 & $1981-1985$ & $\begin{array}{l}\text { The main directions of economic and social } \\
\text { development of the USSR for 1981-1985. and for } \\
\text { the period until } 1990\end{array}$ & XI Five Year Plan \\
\hline 12 & $1986-1990$ & $\begin{array}{l}\text { The main directions of economic and social } \\
\text { development of the USSR for 1986-1990 and for } \\
\text { the future up to the year } 2000\end{array}$ & XII five year plan \\
\hline 13 & $1991-1995$ & $\begin{array}{l}\text { Adopted at the First Congress of People's Deputies } \\
\text { of the USSR in June 1989. It was not implemented } \\
\text { due to the collapse of the USSR }\end{array}$ & XIII five year plan \\
\hline
\end{tabular}

In accordance with the realities of a planned economy, annual planning was carried out more systematically than in the conditions of today's construction complex and the market as a whole. Naturally, this is due to the constant values of the initial (input) data in the planning system and clear indicators that should be reflected in the plan (see Table 3 ). 
Table 3. Input data in the system of annual planning for the formation of the construction and financial plan of a building enterprise, association or trust.

\begin{tabular}{|c|l|}
\hline No. & \multicolumn{1}{|c|}{ Name of input parameter (indicator) } \\
\hline 1. & $\begin{array}{l}\text { Terms of commissioning production facilities and facilities, including the increase in } \\
\text { capacity due to technical re-equipment and reconstruction of existing enterprises }\end{array}$ \\
\hline 2. & The volume of marketable products \\
\hline 3. & Labor productivity growth \\
\hline 4. & The limit of the number of workers and employees \\
\hline 5. & Payroll fund \\
\hline 6. & Profit \\
\hline 7. & Payments to the budget and budget allocations \\
\hline 8. & $\begin{array}{l}\text { The task of the introduction of new technology (scientific organization of labor and } \\
\text { production) }\end{array}$ \\
\hline 9. & $\begin{array}{l}\text { Volume of supplies of materials, machinery, mechanisms and other material and } \\
\text { technical resources }\end{array}$ \\
\hline 10. & Other indicators set by the company, association or trust \\
\hline
\end{tabular}

Based on the above data, the positions of the indicators are generated, which are given in the construction and financial plan. From here, its terminal structure is formed with all internal interconnected subsections of the annual planning system (see Table 4,5).

Table 4. Indicators of construction and financial (estimation) plan of a construction enterprise, association or trust (in the conditions of the state's planned economy).

\begin{tabular}{|c|l|}
\hline No. & \multicolumn{1}{|c|}{$\begin{array}{c}\text { Initial indicators of the annual plan of the construction company, reflected in the } \\
\text { relevant sections of the construction and financial plan }\end{array}$} \\
\hline 1. & Volumetric statement of construction products \\
\hline 2. & Volume list of contract work \\
\hline 3. & Statement of calculation of physical volumes of work \\
\hline 4. & Technical development plan (economic efficiency of the enterprise) \\
\hline 5. & Labor plan \\
\hline 6. & Logistics plan \\
\hline 7. & Plan your own capital investments \\
\hline 8. & Profit plan \\
\hline 9. & Plan to reduce the cost of construction and installation works \\
\hline 10. & Estimated use of funds for economic incentives \\
\hline 11. & Financial plan \\
\hline
\end{tabular}

Table 5. Structure of construction and financial (estimation) plan of a building enterprise, association or trust.

\begin{tabular}{|c|l|}
\hline No. & \multicolumn{1}{|c|}{ The structure of the annual plan of the construction company (15 sections) } \\
\hline 1. & Production Efficiency Plan \\
\hline 2. & $\begin{array}{l}\text { Construction plan for the year (program of the construction company) - Annual } \\
\text { program }\end{array}$ \\
\hline 3. & Technical development plan \\
\hline 4. & Mechanization plan \\
\hline 5. & Labor plan \\
\hline 6. & Subsidiary production plan \\
\hline 7. & Logistics and Equipment Plan \\
\hline 8. & Plan your own capital investments \\
\hline 9. & Profit plan and cost reduction of construction and installation works \\
\hline 10. & Plan for the formation and use of economic incentive funds \\
\hline
\end{tabular}




\begin{tabular}{|c|l|}
\hline No. & \multicolumn{1}{|c|}{ The structure of the annual plan of the construction company (15 sections) } \\
\hline 11. & Financial plan (balance of income and expenses) \\
\hline 12. & Plan for the development and use of production capacity \\
\hline 13. & Social development plan \\
\hline 14. & Plan for conservation and rational use of natural resources \\
\hline 15. & $\begin{array}{l}\text { Calculation of the consolidated plan for all enterprises and organizations of the } \\
\text { association (trust) }\end{array}$ \\
\hline
\end{tabular}

In this form, as of today, production and estimation plan (annual building production and economic plan) does not exist in the planning system of companies (even the largest representatives of the building complex segment), which is primarily due to the innovative mechanisms of the modern market economy, which contribute a large number of destabilizing factors in the planning of construction production for the annual program. At the same time, it is clear, that modern annual production and economic models of an enterprise include in their own structure elements of a production and estimation plan (the concept of a state model with a planned economic system), such as the production program - one of the main elements of a production and estimation plan - remains unchanged. Moreover, the issues of optimization of the production program decisions (including the optimal methodologies for the formation of calendar schedules for program objects) are an extremely relevant area of knowledge and further scientific research.

\section{Materials and Methods}

If we describe the mechanism for the formation of the annual plan of a construction enterprise in a planned economy (within the framework of the implementation of the construction production and estimation plan), we obtain the following scheme.

As for the USSR (until 1991), the state was conditionally divided into areas dominated by certain ministries specializing in a specific industry. For example, in the Ural part of the USSR, the ministry "Mintyazhstroy" had priority, in the European part - the Ministry of Industry and Construction, and so on.

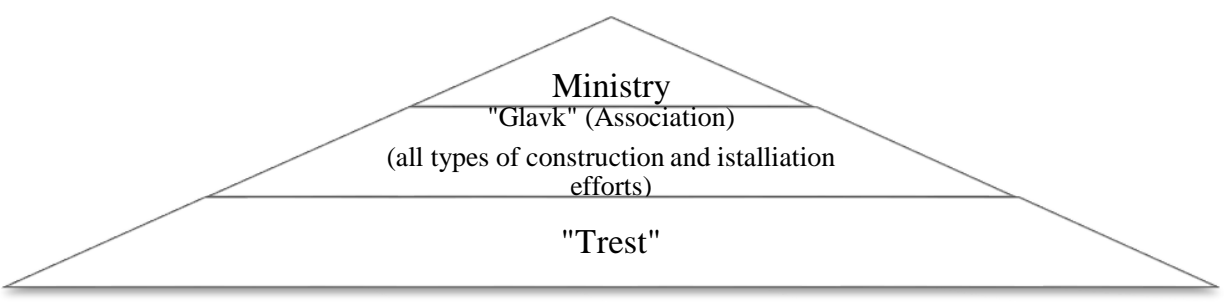

Fig. 1. Hierarchical structure of construction management in a planned economy.

According to the results of the next congress of the CPSU (once every 5 years), a directive on the directions of the country's development was approved (published in the state newspaper "Pravda"). This directive was worked out by the State Planning Committee according to two fundamental schemes - sectoral and territorial, the plan was approved at the level of the State Planning Committee of the region. Further, the Ministry transferred (lowered) the planned scope of work to the level below - subordinate to "Glavk" and "Trusts", according to the results of which the Title lists were formed, which regulate the plan for putting the program objects into operation by year. Thus, usually by the 1st March of each year, the Trust had information about its stable annual planned scope of work for the implementation of a corresponding number of objects that requires a constant distribution of a resource after planning (a static resource management system). 
However, before the period of the so-called "Perestroika" ("Conversion"), the originally approved plan for the introduction of production and residential capacities could be disrupted due to the impact of destabilizing factors on the building production system. These failures of the previously static and stable system of the planned production cycle began to violate the pre-existing balance in the industry, the planned pace of production of finished construction products was disrupted. Under these conditions, the CPSU adopted an unscheduled decision on additional volumes of construction products and sent it to the State Planning Committee and the relevant ministries. The system of resource regulation in the "Trusts" began to acquire the features of a dynamic system, changing under the influence of the external environment.

$$
R+\Delta R \rightarrow P, \text { where }
$$

$P$ - the final finished product (for example, steel) of the industry (construction, engineering, etc.) that requires a certain resource availability;

$R$ - initial raw material resource;

$\Delta R$ - additional resource requirements resulting from import deliveries (if foreign currency is available) or as a result of the construction of new compensating plants.

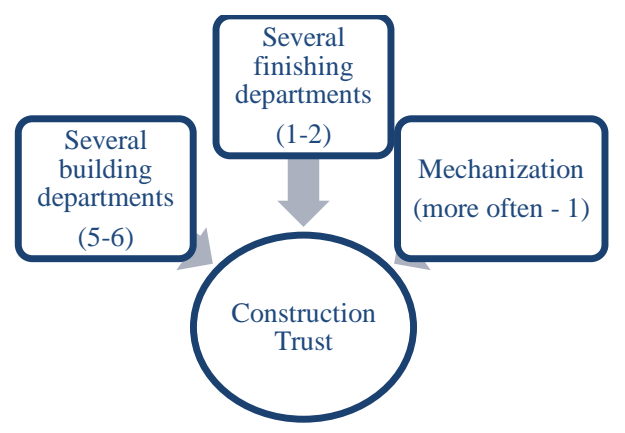

Fig. 2. Typical the structure of a large construction organization in a planned economy (Trust or "Trest") based on an analysis of the activities of existing facilities - representatives.

In the conditions of modern economy, the balance by branches is broken even more significantly, the entropy nature of changes and additions to the program with new objects (of a different order of criticality) is widespread. It becomes obvious that optimization processes are becoming a tool to reduce risks and material costs in the process of implementing the projects of the construction company's production programs. Along with the existing developments in the field of optimization of scheduling and resource allocation planning [1-13], the authors propose a more extensive optimization algorithm for managers during the formation of production programs.

\section{Results and Discussion}

The basic principle of construction of the developed algorithm is that the costs (volume) of the amount of labor resources for all objects of the production program in a specific crosssection of the resource schedule should be minimal (formula 2).

$$
\Delta \sum_{1}^{n}\left(R_{1}+R_{2}+\cdots+R_{n}\right) \rightarrow \min , \text { where }
$$

$R_{1}$ - Resource consumption for object number 1 of the production program of the construction program;

$R_{2}$ - Resource consumption for object number 2 of the production program of the construction program; 
$R_{n}-$ Resource consumption for object number $\mathrm{N}$ of the production program of the construction program;

$n$-the number of objects of the production program in the range $n \in[1 ; n]$.

Table 6. Features of static and dynamic resource allocation systems.

\begin{tabular}{|c|c|c|}
\hline No. & $\begin{array}{l}\text { Features of the static } \\
\text { resource allocation } \\
\text { system in a planned } \\
\text { economy }\end{array}$ & $\begin{array}{l}\text { Features of the dynamic resource allocation system in a } \\
\text { modern market economy }\end{array}$ \\
\hline 1 & \multirow{4}{*}{$\begin{array}{l}\text { Trusts have a clear } \\
\text { sectoral and } \\
\text { technological } \\
\text { specialization, in } \\
\text { accordance with which } \\
\text { the production plan and } \\
\text { programs were created. }\end{array}$} & $\begin{array}{l}\text { Modern construction companies "adapt" to orders on the } \\
\text { market }\end{array}$ \\
\hline 2 & & $\begin{array}{l}\text { Reducing the level of mechanization and automation of } \\
\text { construction due to the impossibility of the preventive } \\
\text { formation of such a diverse fleet of construction machines and } \\
\text { sets of mechanisms and tools }\end{array}$ \\
\hline 3 & & $\begin{array}{l}\text { Reducing the skill level of workers in the construction } \\
\text { industry (with the potential for hiring additional personnel in } \\
\text { the labor market, it is not possible to form a trained and } \\
\text { qualified team in practice in such a short time) }\end{array}$ \\
\hline 4 & & Lack of material incentives \\
\hline 5 & \multirow{3}{*}{$\begin{array}{l}\text { Constant resource } \\
\text { consumption in } \\
\text { accordance with the } \\
\text { approved plan and } \\
\text { programs (the approved } \\
\text { plan was rarely } \\
\text { violated) }\end{array}$} & $\begin{array}{l}\text { Intuitive dynamic distribution of resources in time over } \\
\text { objects in the absence of an approved algorithm }\end{array}$ \\
\hline 6 & & $\begin{array}{l}\text { Emergency attraction of a resource from the outside when } \\
\text { adding a new object to the established production program }\end{array}$ \\
\hline 7 & & $\begin{array}{l}\text { The national problem in the construction industry, associated } \\
\text { with the use of a large proportion of foreign personnel due to } \\
\text { the uncompetitiveness of the domestic labor market and the } \\
\text { operational need to increase the overall intensity of resource } \\
\text { consumption when adding a new object to the established } \\
\text { production program }\end{array}$ \\
\hline 8 & $\begin{array}{l}\text { Uniformly loaded front } \\
\text { of work during } \\
\text { construction }\end{array}$ & $\begin{array}{l}\text { Due to the chaotic transfer of labor on the objects of the } \\
\text { critical path of the production program, the fronts of work are } \\
\text { loaded unevenly }\end{array}$ \\
\hline
\end{tabular}

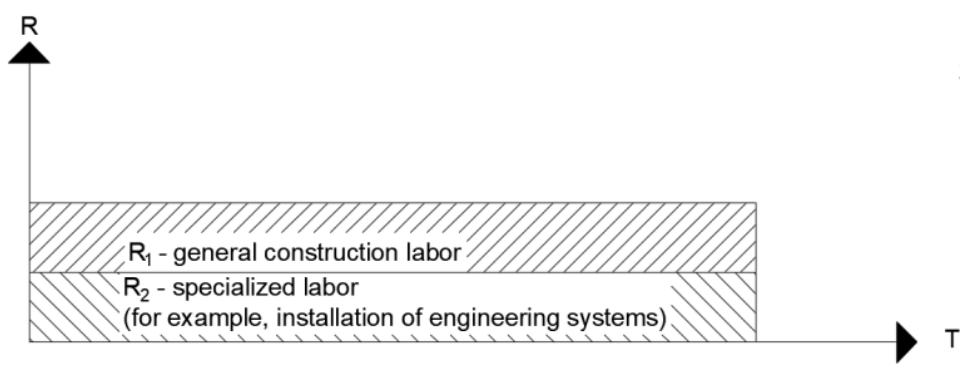

Fig. 3. Typical scheme of resource allocation of a large (by capacity) construction enterprise at the end of the year.

In this case, the costs (volumes) mean the difference between the planned (see Fig. 4) and actual resource consumption (formula 3 ).

$$
\sum_{1}^{n}\left(R_{\text {theor }}-R_{\text {fact }}\right) \rightarrow \min , \text { where }
$$




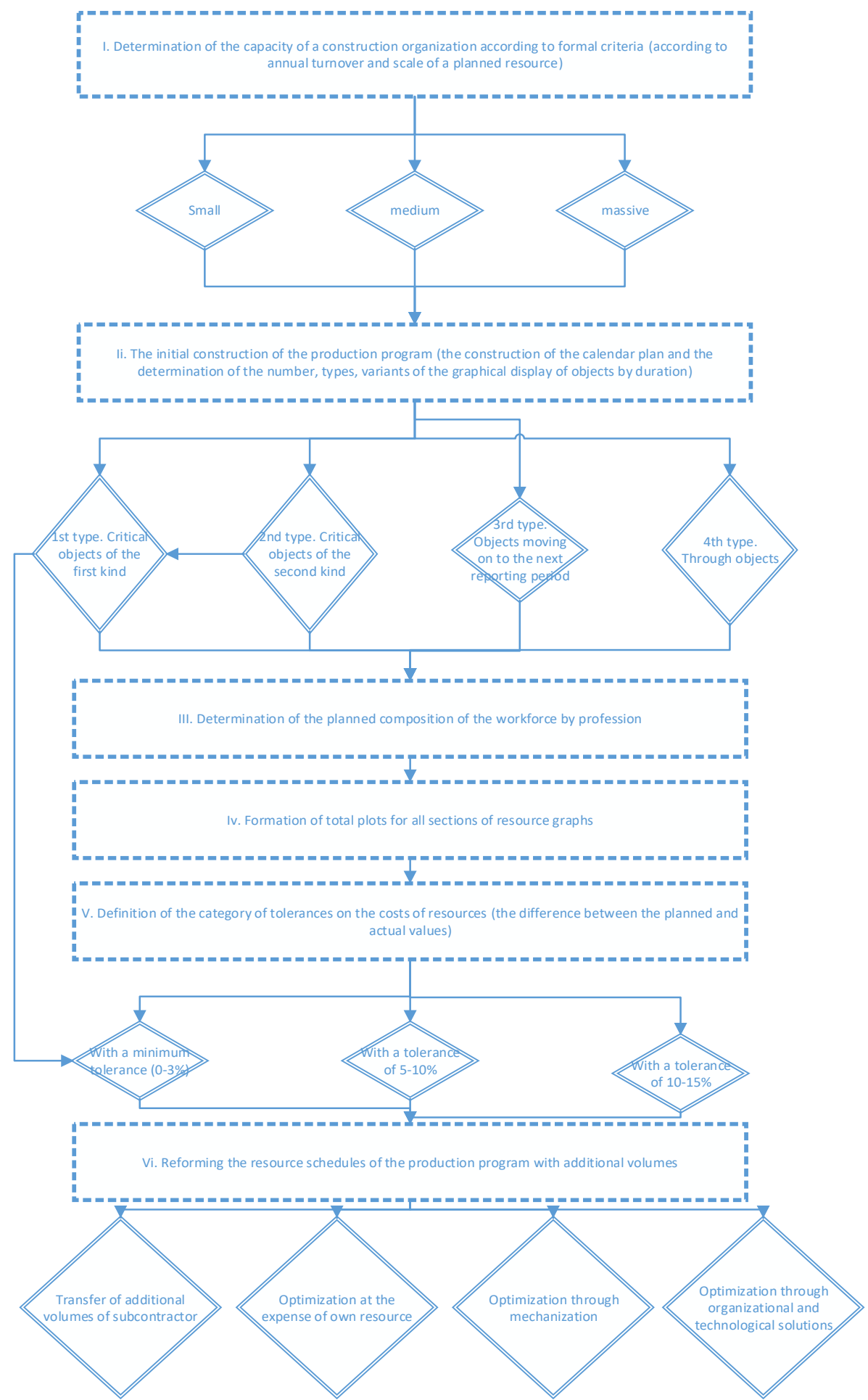

Fig. 4. Truncated optimization algorithm for the formation of the production program of a construction enterprise by resource. 
$R_{\text {theor }}$ - theoretical resource consumption by program objects, equal to the constant planned value;

$R_{\text {fact }}$ - actual resource consumption by program objects;

$n$ - the number of objects of the production program in the range $n \in[1 ; n]$.

As a limitation of the optimization algorithm, the following condition applies (formula 4):

$$
T \leq T_{\text {dir }}, \text { where }
$$

$T$ - total actual time of work at the facility approved by the production program;

$T_{d i r}$ - the directive deadline for performing work at the facility in accordance with the construction contract.

A truncated algorithmic approach to the process of planning and allocating resources will be represented by the following block scheme (see Fig. 4).

\section{Conclusions}

The purpose of modern business to enter the small business segment becomes unwarranted - such small enterprises in an unstable economy and in the absence of a standardized algorithm for current planning (in close connection with the strategic), unable to cover different types of objects offered in the market of construction and engineering services, simply become uncompetitive. The significant difference between the planned and actual indicators of resources in case of adding a new object at the stage of formation of the production program often does not allow for a smooth redistribution of resources between new and existing volumes of construction and installation works. Algorithmization of the process of such planning would allow small and medium-sized organizations to function on a par with large holdings, since the mechanism for distributing the resource field in this case takes a clear mathematical and technological look, justifying the enterprise's managers the current planning solution — to include a new object in the production program, or this step will bring significant risks.

\section{References}

1. I.A. Androsova, S.N. Panarin, Optimization of formation of flows for complex teams PMK, Organization and planning of construction production, management of construction organization (1988)

2. V.P. Astashenkov, Calculation of the optimal order of construction of objects of the town-planning complex, Organization and planning of construction production, management of the construction organization (1988)

3. V.A. Afanasyev, A.V. Afanasyev, Formation, calculation and optimization of flows with limited initial data, Organization and planning of construction production, management of a construction organization (1988)

4. P. Oleinik, A. Yurgaytis, MATEC Web of Conferences 117 (2017)

5. D. Topchiy, A. Shatrova, A. Yurgaytis, MATEC Web of Conferences 193 (2018)

6. P. Oleinik, A. Yurgaytis, MATEC Web of Conferences 193 (2018)

7. M. Rogalska, W. Bozejko, Z. Hejducki, Time/cost optimization using hybrid evolutionary algorithm in construction project scheduling, Automation in Construction (2008)

8. W. Bozejko, Z. Hejducki, M. Uchroński, M. Wodecki, Journal of Civil Engineering and Management (2014) 
9. W. Bozejko, Z. Hejducki, M. Wodecki, Journal of Civil Engineering and Management (2012)

10. M. Rogalska, W. Bozejko, Z. Hejducki, M. Wodecki, Development of time couplings method using evolutionary algorithms, ISARC 2008 - Proceedings from the 25th International Symposium on Automation and Robotics in Construction (2008)

11. M. Rogalska, Z. Hejducki, Journal of Civil Engineering and Management (2007)

12. Z. Hejducki, M. Rogalska, Journal of Civil Engineering and Management (2005)

13. Z. Hejducki, Sequencing problems in methods of organizing construction processes (Engineering, Construction and Architectural Management, 2004)

14. Z. Hejducki, Journal of Civil Engineering and Management (2003)

15. Z. Hejducki, J. Mrozowicz, Stream methods of construction work organization: An introduction to the problem (Engineering, Construction and Architectural Management, 2001) 